\title{
Pengelolaan sampah dengan pendekatan Asset-Based Community Development $(A B C D)$ di wilayah pesisir Bulukumba Sulawesi Selatan
}

\section{Fatmawaty Mallapiang ${ }^{(\mathbb{D})}$, Yessy Kurniati(i), Sukfitrianty Syahrir, Abd. Majid HR Lagu, \& Rimawati Aulia Insani Sadarang}

Program Studi Kesehatan Masyarakat, Fakultas Kedokteran dan IImu Kesehatan, Universitas Islam Negeri Alauddin Makassar, Indonesia

*yessy.kurniati@uin-alauddin.ac.id

\begin{abstract}
Waste becomes a crucial problem in coastal areas because of the habit of people who throw garbage directly into the sea. This community service aims to manage waste by empowering assets owned by the community. This activity is carried out in 2 stages, namely the preparation and implementation stages. The preparation phase is carried out by inventorying assets owned by the community, conducting socialization, preparing materials and materials needed for waste management training. The identified assets owned by the community consist of physical assets, human assets, social assets, financial assets, and natural assets. The results of the activity showed that the participants who were present did not reach the target due to the sea fishing activities carried out by residents. Participants who took part in the waste management activities were quite enthusiastic in participating in the material and simulation. It is expected that participants who follow the training can process their garbage and motivate other residents to handle their waste.
\end{abstract}

\begin{abstract}
Abstrak Sampah menjadi masalah yang krusial di daerah pesisir karena kebiasaan masyarakat yang membuang sampah langsung ke laut. Kegiatan pengabdian ini bertujuan untuk mengelola sampah dengan memberdayakan aset yang dimiliki oleh masyarakat. Kegiatan ini dilakukan dalam 2 tahap, yaitu tahap persiapan dan pelaksanaan. Tahap persiapan dilakukan dengan menginventarisi aset yang dimiliki oleh masyarakat, melakukan sosialisasi, mempersiapkan materi dan bahan yang dibutuhkan untuk pelatihan pengolahan sampah. Aset yang teridentifikasi dimiliki oleh masyarakat terdiri dari aset fisik, aset manusia, aset sosial, aset finansial, dan aset alam, berupa lahan perkebunan dan pertanian yang menjadi sumber sampah organik sekaligus sebagai tempat mengaplikasikan pupuk kompos hasil pengolahan sampah organik tersebut. Hasil kegiatan menunjukkan bahwa peserta yang hadir tidak mencapai target karena kegiatan melaut yang dilakukan warga. Peserta yang mengikuti kegiatan pengolahan sampah cukup antusias mengikuti materi dan simulasi. Diharapkan peserta yang mengikuti pelatihan dapat mengolah sampahnya sendiri dan memotivasi warga lain untuk mengolah sampahnya masing-masing.
\end{abstract}

Keywords: community asset; empowerment; garbage; coastal; $\mathrm{ABCD}$; organic; plastic; sea

\section{¿ OPEN ACCESS}

Citation: Mallapiang, F., Kurniati, Y., Syahrir, S., Lagu, A.M.H.R., \& Sadarang, R.A.I. (2020). Pengelolaan sampah dengan pendekatan Asset-Based Community Development (ABCD) di wilayah pesisir Bulukumba Sulawesi Selatan. Riau Journal of Empowerment, 3(2), 79-86. https://doi.org/10.31258/raje.3.2.79-86

Paper type: Community service

Received: 2020-03-06 Revised: 2020-07-10 Accepted: 2020-07-14

Language: Bahasa Indonesia (id)

ISSN 2623-1549 (online), 2654-4520 (print)

(C) 2020 Fatmawaty Mallapiang et al. Author(s) retain the copyright of article published in this journal, with first publication rights granted to Riau Journal of Empowerment. The article is licenced under Creative Commons Attribution 4.0 International License. This license permits unrestricted use, distribution, and reproduction in any medium, provided the original author and source are credited. 


\section{PENDAHULUAN}

World Health Organization (WHO) mendefinisikan sampah sebagai sesuatu yang tidak digunakan, tidak dipakai, tidak disenangi atau sesuatu yang dibuang yang berasal dari kegiatan manusia dan tidak terjadi dengan sendirinya. Sedangkan definisi sampah menurut Undangundang Republik Indonesia No. 18 tahun 2008 tentang pengelolaan sampah, adalah sisa kegiatan sehari-hari manusia dan atau proses alam yang berbentuk padat. Berdasarkan definisi tersebut terlihat bahwa setiap aktivitas manusia akan menghasilkan sisa kegiatan yang disebut sampah (Susilowati, 2014). Masyarakat menganggap sampah sebagai benda yang tidak bernilai ekonomis sehingga tidak diinginkan lagi (Subekti, 2018).

Peningkatan pola konsumsi masyarakat yang disebabkan karena meningkatnya jumlah penduduk menyebabkan jumlah produksi sampah juga meningkat. Di sisi lain, kapasitas penanganan sampah yang dilakukan masyarakat maupun pemerintah daerah belum optimal. Sampah yang tidak dikelola dengan baik akan berdampak buruk terhadap lingkungan dan kesehatan masyarakat sekitarnya (Riswan et al., 2011). Dampak limbah rumah tangga yang dibuang secara sembarangan akan mengakibatkan menurunnya kualitas air dan tidak dapat dipergunakan lagi. Sedangkan dampak pembuangan limbah ke laut akan mengakibatkan perubahan pada air laut yang akan mengancam kehidupan ekosistem di dalamnya (Hasibuan, 2016).

Salah satu wilayah pesisir yang berada di Wilayah Kabupaten Bulukumba Sulawesi Selatan adalah Desa Gunturu Kecamatan Herlang. Wilayah ini termasuk daerah dataran rendah dengan ketinggian 0-25 meter di atas permukaan laut. Desa Gunturu memiliki luas wilayah sebesar 4841, 18 ha. Wilayah tersebut terdiri dari 44 ha wilayah persawahan, 1100 ha wilayah perkebunan, 2004 ha wilayah hutan. 1758 ha wilayah permukiman dan 430 ha sisanya adalah lahan lainnya. Desa Gunturu memiliki jumlah penduduk sebanyak 3326 jiwa yang terdiri dari 1609 orang laki-laki dan 1707 orang perempuan. Secara umum mata pencaharian penduduk didominasi oleh petani/pekebun dan nelayan (Profil Desa Gunturu, 2018).

Berdasarkan hasil pendataan yang dilakukan sebelumnya ditemukan sekitar 87,7 \% rumah tangga di Desa Gunturu membuang sampahnya ke laut atau pantai. Masyarakat yang tinggal di daerah pesisir memang sering membuang sampah ke laut sehingga menyebabkan masalah pencemaran lingkungan. Kebiasaan masyarakat pesisir di Desa Gunturu hampir serupa dengan masyarakat di Kelurahan Dufa-dufa Kota Ternate. Kebanyakan masyarakat di daerah tersebut membuang sampah di selokan sehingga menyebabkan terjadinya banjir ketika hujan turun. Dan masyarakatnya yang tinggal di daerah pesisir pantai membuang sampah langsung ke laut (Sahil et al., 2016). Studi lain tentang pengelolaan sampah di daerah pesisir Kota Ternate menunjukkan bahwa pengelolaan sampah rumah tangga masyarakat pemukiman Atas Laut masih tergolong sangat rendah. Karena 90,47\% warga tidak memiliki tempat penampungan sampah di dalam rumah, dengan alasan setiap sampah yang ada langsung dibuang ke laut (Rosnawati et al., 2017).

Pengelolaan sampah berbasis masyarakat adalah upaya penanganan sampah yang melibatkan partisipasi aktif dari masyarakat untuk mengelola sampah, mulai dari tahap penimbunan, pengumpulan, pengolahan hingga pemrosesan akhir (Dwiyanto, 2011). Program pemberdayaan masyarakat melalui pengelolaan sampah organik dan anorganik sangat penting dan strategis sebagai upaya pembangunan lingkungan berbasis masyarakat, yaitu mengupayakan peran serta atau partisipasi masyarakat. Langkah ini bukan hanya dilakukan untuk mengurangi penumpukan sampah saja, namun juga untuk memberdayakan masyarakat 
agar peduli terhadap lingkungan. Pemberdayaan masyarakat dalam sampah sangat beragam, seperti mengolah sampah organik menjadi kompos dan mendaur ulang sampah anorganik menjadi perkakas yang dapat digunakan kembali

Beberapa kegiatan pemberdayaan masyarakat dalam penanganan sampah adalah seperti Mallapiang et al. kegiatan pemberdayaan masyarakat dengan metode Community Based Participatory dengan peserta sebanyak 21 orang telah dilakukan di Desa Petir, Kecamatan Petir, Kabupaten Serang. Kegiatan yang diikuti oleh ibu PKK dan remaja putri tersebut berhasil meningkatkan pemahaman peserta tentang pengolahan sampah sebesar $80 \%$. Kegiatan tersebut memberi kesempatan kepada warga untuk belajar mengolah sampah sehingga bernilai ekonomis (Agus et al., 2019). Selain itu, pelatihan pengelolaan sampah rumah tangga dengan metode pemilahan sampah dapat meningkatkan pengetahuan warga dalam hal memilah sampah organik dan anorganik (Tamyiz et al., 2018). Pelatihan pengolahan sampah rumah tangga di Desa Penjaring menunjukkan bahwa setelah pelatihan masyarakat memahami dan terampil dalam mengolah sampah rumah tangga, keberadaan bank sampah mulai dikenal oleh masyarakat dan terjadi peningkatan jumlah nasabah bank sampah (Mardhia \& Wartiningsih, 2018).

Salah satu metode untuk memberdayakan masyarakat dalam penyelesaian masalah adalah dengan pendekatan Asset-Based Community Development (ABCD). Teori ini pertama kali dikembangkan oleh John McKnight. Pendekatan ABCD berasumsi bahwa yang dapat menyelesaikan masalah masyarakat adalah masyarakat itu sendiri dan segala usaha perbaikan dimulai dari perbaikan modal sosial (McKnight, 1996). Identifikasi aset yang dilakukan dalam pendekatan tersebut terdiri dari aset manusia, aset fisik, aset alam, aset sosial dan aset finansial (Susilawaty et al., 2018).

Pendekatan ABCD ini tidak hanya digunakan dalam sektor kesehatan saja. Seperti misalnya pada program pelatihan advokasi masyarakat yang diharapkan meningkatkan kesehatan anak. Pendekatan ABCD digunakan untuk membangun kemitraan dan kapasitas komunitas (Hufford et al., 2009). Pendekatan ABCD juga digunakan untuk meningkatkan kualitas hidup keluarga miskin di pemukiman kumuh Addis Ababa, Ethiopia (Yeneabat \& Butterfield, 2012) serta mengembangkan pariwisata di Tibet (Wu \& Pearce, 2014). Bahkan pendekatan ini digunakan pula untuk menyelenggarakan pertandingan olahraga (Misener \& Schulenkorf, 2016). Metode ini menjadi efektif bila diintegrasikan dengan metode pemberdayaan masyarakat lainnya. Seperti Sustainable Livelihoods (SL) (Nel, 2015), RightsBased Approach (RBA) dan Participatory Rural Approach (PRA) (Khadka, 2012) untuk saling melengkapi dan menguatkan dalam menyelesaikan permasalahan masyarakat

Dengan melihat permasalahan sampah yang terjadi di Desa Gunturu, maka perlu dilakukan pemberdayaan masyarakat dalam mengolah sampah tersebut. Pemberdayaan masyarakat dapat dilakukan dengan pendekatan $\mathrm{ABCD}$ yang menginventarisi terlebih dahulu aset yang dimiliki oleh masyarakat untuk digunakan sebagai sumber daya dalam pengolahan sampah.

\section{METODE PENERAPAN}

Pada dasarnya pelaksanaan kegiatan ini dibagi menjadi 2 tahap, yaitu tahap persiapan dan tahap pelaksanaan. 


\section{Tahap Persiapan}

Pada tahap persiapan dilakukan serangkaian kegiatan untuk memberdayakan masyarakat dalam melakukan pengolahan sampah. Adapun kegiatan yang dilakukan pada tahap persiapan yaitu melakukan sosialisasi dan koordinasi kepada aparat desa, kepala dusun maupun ketua RT/RW serta organisasi pemuda dan kader posyandu. Kegiatan ini dilakukan untuk mendapat dukungan serta menginformasikan tentang pelaksanaan kegiatan kepada masyarakat. Selanjutnya mempersiapkan materi tentang pengolahan sampah organik menggunakan komposter dan pengolahan sampah anorganik dengan memilah sampah untuk dijadikan bahan kerajinan tangan/hiasan. Terakhir, pada tahap ini, mempersiapkan komposter dan contoh sampah anorganik yang dipilah sesuai jenisnya untuk diolah menjadi kerajinan tangan.

\section{Tahap Pelaksanaan}

Pada tahap pelaksanaan kegiatan ini dilakukan dalam tiga tahapan yaitu (1) melakukan inventarisir aset masyarakat yang dapat digunakan dalam pengolahan sampah, (2) pelatihan pengolahan sampah organik menggunakan komposter, dan (3) pelatihan pengolahan sampah anorganik menjadi kerajinan tangan/hiasan.

\section{HASIL DAN KETERCAPAIAN SASARAN}

\section{Aset Masyarakat}

Kegiatan pemberdayaan masyarakat berbasis aset ini dimulai dengan menginventarisi aset masyarakat Desa Gunturu. Berdasarkan hasil observasi, ditemukan beberapa aset yang dimiliki oleh masyarakat Desa Gunturu yang dapat dimanfaatkan dalam kegiatan pengolahan sampah. Aset-aset yang teridentifikasi tersebut dikategorikan menjadi aset fisik, manusia, sosial, finansial, dan alam.

Aset fisik berupa bangunan/fasilitas yang dapat dimanfaatkan dalam pelaksanaan kegiatan, yaitu rumah kepala dusun yang dapat dijadikan pelaksanaan pengolahan sampah organik dan masjid yang dapat dijadikan tempat pelatihan pengolahan sampah anorganik. Aset berikutnya adalah aset manusia, berupa Kepala Dusun dan Ketua RT/RW yang sangat mendukung kegiatan ini. Diharapkan dengan adanya dukungan tersebut dapat menggerakkan warga untuk ikut dalam kegiatan pengolahan sampah secara mandiri dan berkesinambungan. Aset lainnya yang teridentifikasi ialah aset sosial. Aset ini berupa karang taruna dan kader posyandu. Diharapkan anggota karang taruna dan kader posyandu menjadi peserta yang aktif dalam pelaksanaak kegiatan serta dapat menularkan pengetahuan yang diperoleh kepada warga yang lain. Aset finansial berupa warga yang bersedia membantu menyediakan logistic saat pelaksanaan kegiatan. Selain itu, ada pula warga yang menyediakan lahannya untuk dijadikan tempat komposter sampah organik. Terakhir, teridentifikasi adanya aset alam. Aset alam berupa lahan perkebunan dan pertanian yang menjadi sumber sampah organik sekaligus sebagai tempat mengaplikasikan pupuk kompos hasil pengolahan sampah organik tersebut.

Berdasarkan hasil inventarisasi $\mathrm{ABCD}$, maka ada dua kegiatan pengelolaan sampah yang dapat dilakukan di Desa Gunturu, yaitu pelatihan pengolahan sampah organik menggunakan komposter dan pelatihan pengolahan sampah anorganik menjadi kerajinan tangan atau hiasan. 


\section{Pelatihan pengolahan sampah organik menggunakan komposter}

Mallapiang

Sebagian besar peserta adalah anggota karang taruna dan bapak-bapak. Kegiatan diawali dengan pemberian materi tentang cara pemilahan sampah dan cara pembuatan kompos. Setelah materi selesai dilanjutkan dengan simulasi atau latihan pembuatan kompos dengan komposter Minat masyarakat terhadap kegiatan ini masih sangat kurang karena target yang ditetapkan tidak tercapai. Faktor penghambat dari kegiatan ini yaitu di rutinitas yang dilakukan masyarakat adalah melaut sehingga sulit untuk mengumpulkan sasaran sesuai dengan yang direncanakan.

Pemberian materi tentang cara pemilahan sampah ini bertujuan untuk menambah pengetahuan masyarakat mengenai perbedaan sampah organik dan anorganik. Diharapkan setelah mengetahui jenis-jenis sampah, masyarakat dapat memilah dan memisahkan sampah sesuai dengan cara daur ulangnya. Misalnya sampah rumah tangga (organik) diolah menjadi kompos sedangkan sampah plastik (anorganik) diolah menjadi kerajinan tangan. Pemberian materi ini dilakukan dengan metode ceramah sembari menunjukkan alat dan bahan yang digunakan dalam pembuatan komposter (Gambar 1).

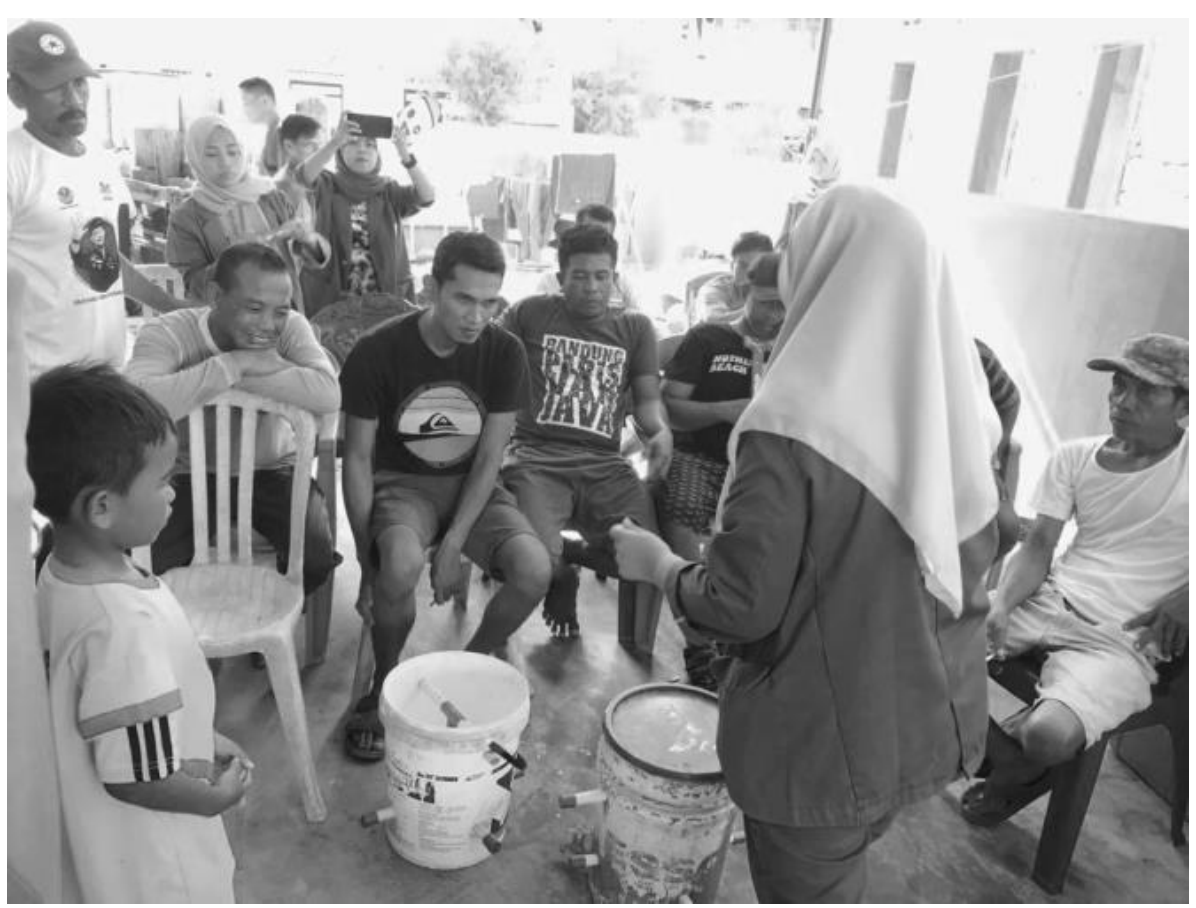

Gambar 1. Demonstrasi pembuatan komposter

Setelah pemberian materi tentang pemilahan sampah, maka dilanjutkan dengan materi tentang pengolahan sampah menjadi kompos menggunakan komposter. Komposter adalah teknologi atau alat yang digunakan untuk mengubah sampah organik menjadi kompos (Hasna, 2021). Pengolahan sampah dengan metode ini sangat cocok diterapkan di Desa Gunturu yang sebagian warganya adalah petani. Dengan menggunakan kompos yang mereka hasilkan sendiri diharapkan akan mengurangi biaya yang dikeluarkan untuk membeli pupuk tanaman. Sedangkan bagi warga yang tidak memiliki lahan pertanian, pembuatan kompos dapat menjadi alternatif sumber ekonomi dengan penjual pupuk tersebut kepada petani yang membutuhkan. Materi diakhiri dengan sesi tanya jawab untuk memperjelas pemahaman peserta tentang materi yang disampaikan. Setelah pemberian materi, kegiatan lalu dilanjutkan dengan demonstrasi pembuatan kompos. Terlihat peserta yang hadir cukup antusias melihat cara pembuatan pupuk 
kompos dengan menggunakan sampah organik. Setelah demonstrasi selesai dilakukan. peserta lalu mencoba mempraktekkan pembuatan kompos seperti yang telah didemonstrasikan (Gambar 2). Hal tersebut dilakukan untuk meningkatkan pemahaman dan keterampilan peserta dalam mengolah sampah organik menjadi pupuk kompos.

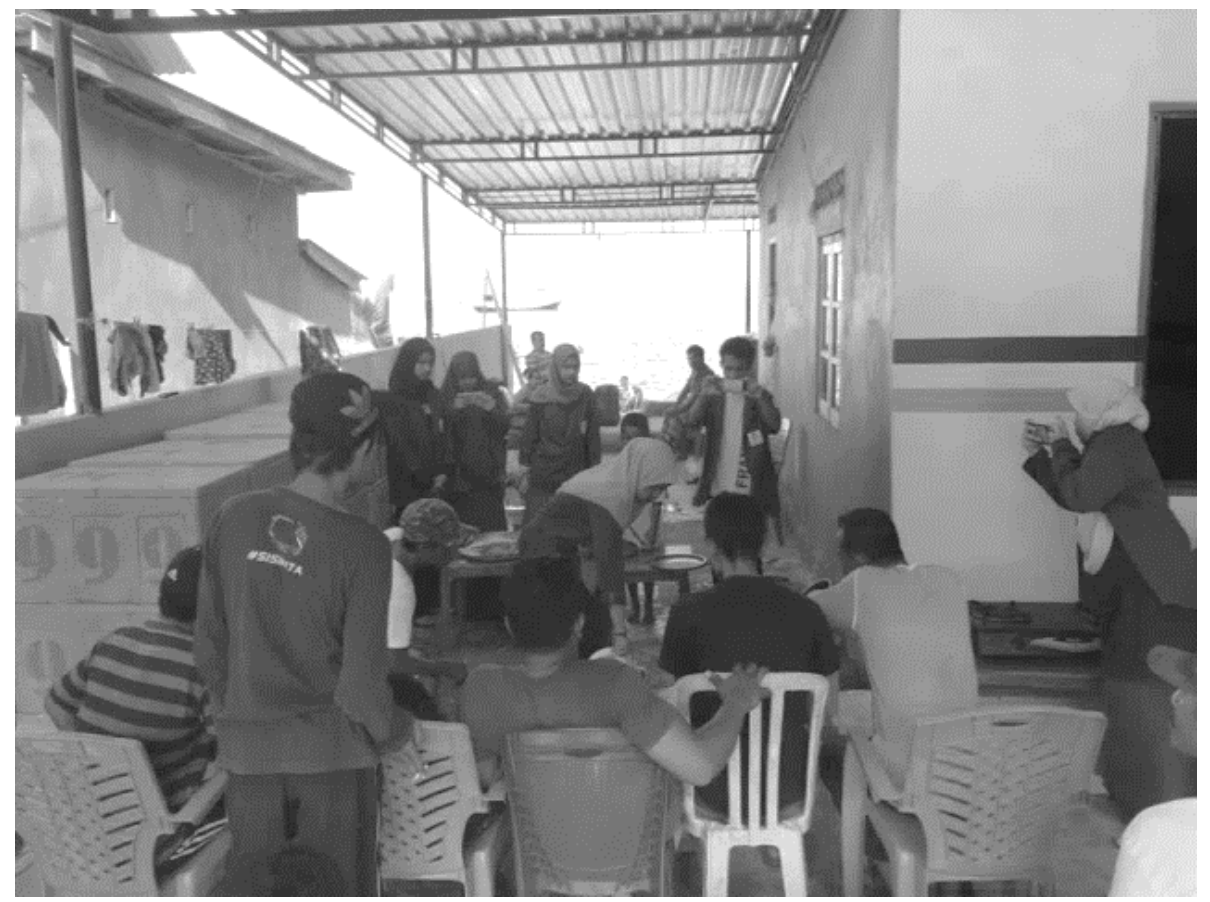

Gambar 2. Pelatihan pembuatan kompos

\section{Pelatihan pengolahan sampah anorganik menjadi kerajinan tangan/hiasan}

Sebagian besar peserta adalah ibu-ibu dan kader posyandu. Kegiatan diawali dengan pemberian materi tentang cara pemilahan sampah kemudian dilanjutkan dengan praktek cara membuat kerajinan tangan dari sampah plastik (Gambar 3). Setelah materi selesai dilanjutkan dengan simulasi atau latihan membuat kerajinan tangan. Setelah pemberian materi, kegiatan dilanjutkan dengan praktek membuat hiasan dari sampah plastik.
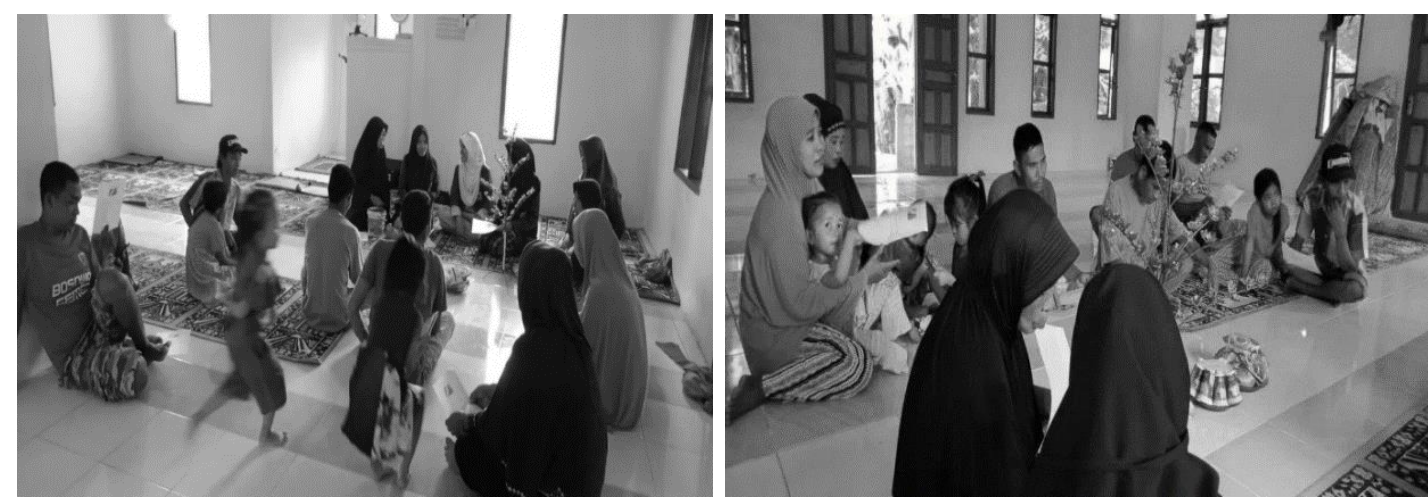

Gambar 3. Pelatihan pengolahan sampah anorganik menjadi kerajinan tangan

Berdasarkan hasil observasi yang dilakukan, sebagian peserta ada yang sudah dapat membuat karya dengan cukup baik, namun sebagian peserta ada yang membuat karya dengan kualitas yang masih rendah. Peserta yang dapat membuat karya kerajinan dengan kualitas yang 
baik, adalah ibu-ibu yang pernah membuat kerajinan tersebut sebelumnya. Sedangkan peserta yang baru pertama kali mendapat pelatihan, menghasilkan karya yang masih perlu diperbaiki.

\section{KESIMPULAN}

Berdasarkan hasil inventaris aset, ditemukan bahwa di Desa Gunturu terdapat aset fisik berupa rumah kepala desa dan masjid yang dapat digunakan sebagai tempat pelaksanaan kegiatan, aset manusia yaitu kepala dusun dan ketua RT/RW yang siap memberikan dukungan, aset sosial yaitu karang taruna dan kader posyandu yang dapat menggerakkan warga untuk berpartisipasi, aset finansial berupa kesediaan warga menyediakan logistik kegiatan dan aset alam berupa lahan perkebunan dan pertanian yang menjadi sumber sampah organik sekaligus tempat untuk menyalurkan pupuk kompos hasil pengolahan sampah. Aset-aset tersebut digunakan untuk menyelesaikan permasalahan sampah yang ada di masyarakat. Penyelesaian masalah dilakukan melalui dua kegiatan, yaitu pelatihan pembuatan komposter dan pelatihan pembuatan kerajinan tangan. Melalui pelaksanaan kegiatan tersebut diharapkan para peserta termotivasi untuk mengolah sampahnya sendiri dan dapat mempengaruhi warga yang lain untuk melakukan pengolahan sampah. Dampak kegiatan yang terlihat beberapa hari setelah pelaksanaan pelatihan komposter, terdapat salah seorang warga yang menyediakan halamannya untuk mengumpulkan sampah-sampah. Kemudian warga tersebut mengundang karang taruna maupun warga lain yang berminat untuk bersama melakukan pemilahan dan pengolahan sampah di halaman rumahnya.

Dengan pelatihan pengolahan sampah ini diharapkan warga tidak lagi membuang sampahnya ke laut dan mendapat manfaat secara ekonomi dari kegiatan pengolahan sampah yang dilakukan. Selain itu, warga diharapkan mengaplikasikan ilmu dari pelatihan yang diberikan, seperti pada pelatihan pembuatan kerajinan atau hiasan, peserta yang belum mampu menghasilkan karya dengan kualitas baik, diharapkan terus berlatih sehingga dapat meningkatkan keterampilannya dalam mengolah sampah anorganik. Kegiatan ini diharapkan dapat membantu menjaga kelestarian lingkungan sekaligus meningkatkan ekonomi masyarakat pesisir di Desa Gunturu.

\section{UCAPAN TERIMA KASIH}

Ucapan terima kasih kami sampaikan kepada Ketua LPPM Universitas Islam Negeri Alauddin Makassar. Selain itu kami juga mengucapkan terima kasih kepada Kepala Desa Gunturu beserta jajarannya, Kepala Dusun, dan Ketua RT/RW untuk segala bantuan dan dukungan yang diberikan selama pelaksanaan kegiatan. Terima kasih juga kami sampaikan kepada warga Desa Gunturu yang telah membantu terlaksananya kegiatan pengabdian ini sehingga kegiatan pengabdian kami dapat berjalan dengan baik.

\section{Daftar Pustaka}

1. Agus, R. N., Oktaviyanthi, R., \& Sholahudin, U. (2019). 3R: Suatu Alternatif Pengolahan Sampah Rumah Tangga. Kaibon Abhinaya: Jurnal Pengabdian Masyarakat, 1(2), 72. https://doi.org/10.30656/ka.v1i2.1538

2. Dwiyanto, B. M. (2011). Model Peningkatan Partisipasi Masyarakat dan Penguatan Sinergi Dalam Pengelolaan Sampah Perkotaan. Jurnal Ekonomi Pembangunan: Kajian Masalah Ekonomi Dan Pembangunan, 12(2), 239. https://doi.org/10.23917/jep.v12i2.196 
3. Hasibuan, R. (2016). Analisis Dampak Limbah/Sampah Rumah Tangga terhadap Pencemaran Lingkungan Hidup. Jurnal Ilmiah Advokasi, 4(1), 42-52.

http://jurnal.ulb.ac.id/index.php/advokasi/article/view/354

4. Hasna, N., Juwana, I., \& Satori, M. (2021). Studi Komparasi Komposter Berbasis Masyarakat. Jurnal Reka Lingkungan, 9(1), 34-44. Advance online publication. https://doi.org/10.26760/rekalingkungan.v9i1.34-44

5. Hufford, L., West, D. C., Paterniti, D. A., \& Pan, R. J. (2009). Community-Based Advocacy Training: Applying Asset-Based Community Development in Resident Education. Academic Medicine, 84(6), 765-770. https://doi.org/10.1097/acm.0b013e3181a426c8

6. Khadka, R. (2012) Switching Gears: From Needs to Assets Based Approach to Community Development in Nepal. OIDA International Journal of Sustainable Development, 03(11), 81-88. https://ssrn.com/abstract=2047887

7. Mardhia, D., \& Wartiningsih, A. (2018). Pelatihan Pengolahan Sampah Skala Rumah Tangga di Desa Penyaring. Jurnal Pendidikan dan Pengabdian Masyarakat, 1(1), 88-96. http://jurnalfkip.unram.ac.id/index.php/JPPM/article/view/492

8. McKnight, J. (1996). The Careless Society: Community and Its Counterfeits. Basic Books.

9. Misener, L., \& Schulenkorf, N. (2016). Rethinking the Social Value of Sport Events Through an Asset-Based Community Development (ABCD) Perspective. Journal of Sport Management, 30(3), 329-340. https://doi.org/10.1123/jsm.2015-0203

10. Nel, H. (2015). An integration of the livelihoods and asset-based community development approaches: A South African case study. Development Southern Africa, 32(4), 511-525. https://doi.org/10.1080/0376835x.2015.1039706

11. Profil Desa Gunturu. (2018). Kantor Desa Gunturu.

12. Riswan, Sunoko, H. R., \& Hadiyarto, A. (2011). Pengelolaan Sampah Rumah Tangga di Kecamatan Daha Selatan. Jurnal Ilmu Lingkungan, 9(1), 31-38. https://doi.org/10.14710/jil.9.1.31-38

13. Rosnawati, W. O., Bahtiar, \& Ahmad, H. (2017). Pengelolaan Sampah Rumah Tangga Masyarakat Pemukiman Atas Laut di Kecamatan Kota Ternate. Techno: Jurnal Penelitian, 6(02), 48-56. https://doi.org/10.33387/tk.v6i02.569

14. Sahil, J., Muhdar, M. H. I. A., Rohman, F., \& Syamsuri, I. (2016). Sistem Pengelolaan dan Upaya Penanggulangan Sampah di Kelurahan Dufa-Dufa Kota Ternate. Jurnal Bioedukasi, 4(2), 478-487. http://ejournal.unkhair.ac.id/index.php/bioedu/article/view/160

15. Subekti, S. (2018). Pengelolaan Sampah Rumah Tangga 3R Berbasis Masyarakat. Paper presented at the Seminar Nasional Sains dan Teknologi.

16. Susilawaty, A., Nurdiyanah, \& Aryadin, A. (2018). Identifikasi Aset Sarana Sanitasi Dasar Dengan Pendekatan Asset Based Community Development (ABCD) di Desa Barugaia Kecamatan Bontomanai Kabupaten Kepulauan Selayar. Al-sihah: Public Health Science Journal, 10(1), 96-107. http://journal.uin-alauddin.ac.id/index.php/Al-Sihah/article/view/5423

17. Susilowati, L. E. (2014). Peran Perempuan Dalam pengelolaan sampah Rumah Tangga Berbasis Program 4P di Wilayah Pesisir Desa Labuhan Haji Lombok Timur. Jurnal Penelitian Unram, $18,96-105$.

18. Tamyiz, M., Hamidah, L. N., Widiyanti, A., \& Rahmayanti, A. (2018). Pelatihan Pengelolaan Sampah Rumah Tangga di Desa Kedungsumur, Kecamatan Krembung, Kabupaten Sidoarjo. Journal of Science and Social Development, 1(1), 16-23.

19. Yeneabat, M., \& Butterfield, A. K. (2012). "We Can't Eat A Road:" Asset-Based Community Development and The Gedem Sefer Community Partnership in Ethiopia. Journal of Community Practice, 20(1-2), 134-153. https://doi.org/10.1080/10705422.2012.650121

20. Wu, M. Y., \& Pearce, P. L. (2014). Asset-based community development as applied to tourism in Tibet. Tourism Geographies, 16(3), 438-456. https://doi.org/10.1080/14616688.2013.824502 